ACTA UNIVERSITATIS LODZIENSIS

FOLIA LITTERARIA POLONICA 3(41) 2017

http://dx.doi.org/10.18778/1505-9057.41.10

Barbara Sobczak* $^{*}$

\title{
Telewizja jako narzędzie propagandy politycznej
}

\author{
Każdy przytomny rewolucjonista albo potencjalny przywódca wie, \\ że jego podstawowym zadaniem jest opanowanie źródła informacji publicznej. \\ Elliot Aronson, Anthony Pratkanis
}

Gdy teraz my jesteśmy odpowiedzialni za rządzenie, to musimy mieć środki masowego przekazu. Grażyna Staniszewska (posłanka Sejmu w 1989)

\section{Wstęp}

Elliot Aronson i Anthony Pratkanis we wstępie do swojej pracy Wiek propagandy piszą: „Ilekroć włączamy radio lub telewizor, ilekroć otwieramy książkę, czasopismo albo gazetę, ktoś próbuje nas edukować, przekonać do zakupu jakiegoś produktu, namówić do oddania głosu na konkretnego polityka albo do przyjęcia określonego poglądu na sprawiedliwość, prawdę i piękno"1. Środki masowego przekazu są podstawowym medium perswazji², a za najskuteczniejszy z nich

\footnotetext{
* Dr, e-mail: barbarasobczak@o2.pl; Uniwersytet im. A. Mickiewicza w Poznaniu, Wydział Filologii Polskiej i Klasycznej, Instytut Filologii Polskiej.

${ }^{1}$ A. Pratkanis, E. Aronson, Wiek propagandy. Używanie i nadużywanie perswazji na co dzień, przeł. J. Radzicki, M. Szuster, Wydawnictwo Naukowe PWN, Warszawa 2005, s. 10.

${ }^{2}$ Perswazję rozumiem, zgodnie z tradycją retoryczną, jako oddziaływanie na rozum, wolę i emocje odbiorcy, którego celem jest kształtowanie jego opinii, postaw, zachowań zgodnie z intencjami nadawcy, przy założeniu, że relacje między nadawcą i odbiorcą są równorzędne i odbiorca ma świadomość wywieranego wpływu, a zatem ma możliwość wyboru. Narzędzia oddziaływania mogą mieć charakter językowy, ale również pozawerbalny. Jeśli odbiorca nie jest świadomy lub nie rozpoznaje stosowanych przez nadawcę zabiegów mamy do czynienia z manipulacją. Nie utożsamiam perswazji z manipulacją, jak uczynił to np. Stanisław Barańczak, definiując funkcję perswazyjną jako „szczególną odmianę funkcji konatywnej, polegającą na usiłowaniu uzyskania realnego wpływu na sposób myślenia lub postępowania odbiorcy, jednakże nie drogą bezpośredniego rozkazu, lecz metodą utajoną i pośrednią, tak iż w wypowiedzi dominuje z pozoru inna niż konatywna funkcja językowa (np. funkcja estetyczna, poznawcza, emotywna itp.)” (S. Barańczak,
} 
uznaje się telewizję, dlatego też telewizja od początku powstania wykorzystywana była przez władzę do dystrybucji propagandy politycznej. Mówiąc ,telewizja”, mam na myśli zarówno instytucję zajmującą się organizowaniem oraz przesyłaniem programów telewizyjnych - a więc stację telewizyjną, jak i sam przekaz telewizyjny, czyli komunikat audiowizualny ${ }^{3}$. Propagandę natomiast rozumiem jako zorganizowane, planowe rozpowszechnianie pewnych idei, doktryn, teorii, poglądów itp., zmierzające do wywołania określonych postaw i zachowań ludzi zgodnych z interesem nadawcy - jednostkowego lub zbiorowego (władzy, partii, innych obywateli itd.) ${ }^{4}$. W takim działaniu treści informacyjne podporządkowane są intencji perswazyjnej, a główną intencją nadawcy propagandy nie jest wyposażenie odbiorców w obiektywną wiedzę, lecz przekonanie ich do własnej wizji świata, wpojenie pożądanych przekonań i dostarczenie gotowych wzorów myślenia. W wymiarze bardziej konkretnym chodzi zazwyczaj o pozyskanie ludzi dla jakiejś idei, akcji, zdobycie zwolenników i sojuszników ${ }^{5}$. Dokonuje się to poprzez szczególny, selektywny dobór treści komunikatów i ukształtowanie jego formy, a także poprzez zastosowanie różnych metod nakłaniania - bezpośrednich lub pośrednich, jawnych lub ukrytych, uczciwych lub nieuczciwych ${ }^{6}$. Propaganda współcześnie jest najbardziej zinstytucjonalizowaną formą komunikowania. Jeśli jej nadawcami są przede wszystkim organizacje i instytucje: rządy, partie, elity polityczne - wówczas mówimy o propagandzie politycznej. W większości przypadków komunikat propagandowy trafia do odbiorcy za pośrednictwem mediów masowych $^{7}$, w tym telewizji.

Oczywiście istotny dla procesu dystrybucji propagandy jest stopień niezależności nadawcy medialnego w konstruowaniu przekazu. W systemach totalitarnych, gdzie istnieje ścisła zależność i kontrola polityczna, informacje rutynowo są cenzurowane przez elity rządzące, a przekaz telewizyjny jest elementem aparatu kształtowania świadomości obywateli, co pokazują doświadczenia chociażby polskie z czasów komunizmu, gdy telewizja, a zwłaszcza programy informacyjne,

Słowo, perswazja, kultura masowa, „Twórczość” 1975, nr 7, s. 49). Zob. Arystoteles, Retoryka I 1356a-1358b, tłum. H. Podbielski, ale też: I. Kamińska-Szmaj, Propaganda, perswazja, manipulacja - próba uporządkowania pojęć, [w:] Manipulacja w języku, red. P. Krzyżanowski, P. Nowak, Wydawnictwo UMCS, Lublin 2004, s. 19-22; R. Grzegorczykowa, Problem funkcji języka i tekstu w świetle teorii aktów mowy, [w:] Język a kultura, t. 4: Funkcje języka $i$ wypowiedzi, red. J. Bartmiński, R. Grzegorczykowa, Wydawnictwo „Wiedza o Kulturze”, Wrocław 1991, s. 24; J. Puzynina, Język wartości, Wydawnictwo Naukowe PWN, Warszawa 1992, s. 203-223.

${ }^{3}$ Zob. P. Fortuna, Psychologiczne mechanizmy obrony przed perswazyjnym wplywem telewizji, Towarzystwo Naukowe KUL, Lublin 2007, s. 14.

${ }^{4}$ I. Kamińska-Szmaj, dz. cyt., s. 17.

${ }^{5}$ O. Thomson, Historia propagandy, przeł. S. Głąbiński, Wydawnictwo „Książka i Wiedza”, Warszawa 2001, s. 14; zob. też B. Dobek-Ostrowska, J. Fras, B. Ociepka, Teoria i praktyka propagandy, Wydawnictwo UWr, Wrocław 1999, s. 8-11; A. Pratkanis, E. Aronson, dz. cyt., s. 17.

${ }^{6}$ I. Kamińska-Szmaj, dz. cyt., s. 17.

${ }^{7}$ B. Dobek-Ostrowska, J. Fras, B. Ociepka, dz. cyt., s. 8. 
takie jak: „Dziennik Telewizyjny”, „Wieczór z Dziennikiem”, „Dziennik Komentarze”, „Dziennik z Okna”, „Monitor”, „Teleexpress”, „Echa Dnia”, „Dziennik 24 godziny" były głównym narzędziem propagandy władz PRL i PZPR. W modelu demokracji zachodnich, gdzie media mają być neutralnymi pośrednikami między władzą a społeczeństwem, jak się czasem mówi - obserwatorami z dystansu, tak jawna kontrola jest czymś rzadkim i wywołuje publiczne protesty, co nie znaczy jednak, że grupy sprawujące władzę nie dążą do przejęcia kontroli nad symbolami, mitami i informacjami rozpowszechnianymi przez telewizję po to, by rozprzestrzeniać swoje wartości. Jak zauważa Beata Ociepka, niezależnie od rozwiązań modelowych, media, w tym telewizja, w każdym systemie są służebne w stosunku do tych, którzy posiadają władzę polityczną i wpływy gospodarcze, a treści wiadomości ukazujących się w środkach masowego przekazu odzwierciedlają interesy tych, którzy je finansują ${ }^{8}$. Podobne stanowisko formułuje Maciej Mrozowski, mówiąc, że „działania mediów masowych uwarunkowane są przez dwojakiego rodzaju czynniki. Z jednej strony, przez regulacje prawne i układ sił politycznych, a z drugiej - przez społeczne oczekiwania, warunki cywilizacyjne i grę interesów"'.

Wpływ mediów na funkcjonowanie współczesnych społeczeństw i świat polityki niewątpliwie jest „zdolnością realną”, wielokrotnie analizowaną z różnych perspektyw $w^{10}$. Media nie tylko informują, ale mają też siłę oddziaływania opiniotwórczego, kształtują system wartości i postawy ludzi ${ }^{11}$. Dzieje się tak dlatego, że dysponują przynajmniej nieformalnym autorytetem. Jak mówi Bogusława Dobek-Ostrowska, posiadają czwarty typ władzy - władzę symboliczną, której moc sprowadza się do zdobywania prestiżu i kapitału zaufania ${ }^{12}$. Ta symboliczna władza mediów wykorzystywana jest w sposób partykularny m.in. przez polityków ${ }^{13}$, zwłaszcza, jeżeli chodzi o media elektroniczne. W latach 30. XX wieku radio było ważnym środkiem propagandy hitlerowskiej ${ }^{14}$. Jako pierwszy w Ameryce

\footnotetext{
${ }^{8}$ B. Ociepka, System propagandowy, [w:] Teoria i praktyka propagandy, dz. cyt., s. 58.

${ }^{9}$ M. Mrozowski, Media masowe. Władza, rozrywka, biznes, Wydawnictwo Aspra-Jr, Warszawa 2001, s. 192.

${ }^{10}$ Zob. np. Mrozowski, Media masowe, dz. cyt.; Władza mediów, red. W. Piątkowska-Stepaniak, A. Drosik, Wydawnictwo UO, Opole 2010; U. Eco, Semiologia życia codziennego, przekł. J. Ugniewska, P. Salwa, Czytelnik, Warszawa 1999; K. Czuba, Media i władza, Ad Astra, Warszawa 1995; Czwarta władza? Jak polskie media wplywaja na opinię publiczna, red. W. Nentwig, Oficyna Wydawnicza „Głos Wielkopolski”, Poznań 1995; M. McLuhan, Zrozumieć media: przedłużenie człowieka, przekł. N. Szczucka, Wydawnictwa Naukowo-Techniczne, Warszawa 2005.

${ }^{11}$ M. Różycka, Panowanie - czy władza - mediów?, [w:] Władza mediów, red. W. Piątkowska-Stepaniak, A. Drosik, Wydawnictwo UO, Opole 2010, s. 50; K. Czuba, dz. cyt., s. 10.

${ }^{12}$ B. Dobek-Ostrowska, Media masowe i aktorzy polityczni w świetle studiów nad komunikowaniem politycznym, Wydawnictwo Uniwersytetu Wrocławskiego, Wrocław 2004, s. 142.

${ }^{13}$ W. Cwalina, A. Falkowski, Marketing polityczny. Perspektywa psychologiczna, Gdańskie Wydawnictwo Psychologiczne, Gdańsk 2005, s. 241.

${ }^{14}$ zob. O. Thomson, dz. cyt, s. 62-64.
} 
telewizję do celów politycznych wykorzystał Dwight Eisenhower. Do jego wygranej w wyborach prezydenckich w 1952 roku przyczyniła się jedna z amerykańskich sieci telewizyjnych - Columbia Broadcasting System, która relacjonowała przebieg kampanii wyborczej ${ }^{15}$. Od tamtej pory telewizja zaczęła w istotny sposób wpływać na rezultaty wyborów nie tylko w Ameryce, ale też w Europie, żeby wspomnieć chociażby słynną debatę Jacques'a Chiraca z Lionelem Jospinem we Francji (2002) czy w Polsce - debaty Lecha Wałęsy i Aleksandra Kwaśniewskiego (w kampanii prezydenckiej w 1995 roku) albo Donalda Tuska z Jarosławem Kaczyńskim w 2007 roku ${ }^{16}$.

Rola mediów w procesie kształtowania opinii publicznej nie ulega wątpliwości. Mnie jednak interesuje odpowiedź na pytanie, w czym tkwi potencjał perswazyjny telewizji i w związku z tym - jak wygląda jej użyteczność w działaniach propagandy politycznej.

\section{Analiza materiału}

Przedmiotem analizy uczyniłam program emitowany w TVP Info - kanale informacyjnym telewizji publicznej (państwowej), dnia 10 kwietnia 2016 roku, od godz. 8.20 do godz. 22.30. Był to dzień uroczystych obchodów szóstej rocznicy katastrofy smoleńskiej, w której zginęło 96 osób, w tym ówczesny prezydent RP Lech Kaczyński z małżonką ${ }^{17}$. Uroczystości rocznicowe zorganizowane przez Prawo i Sprawiedliwość miały swój oficjalny, państwowy wymiar. Tragiczne wydarzenie uczciły też władze Warszawy na Powązkach przy pomniku Ofiar Katastrofy Lotniczej pod Smoleńskiem; Platforma Obywatelska w Gdańsku, m.in. na cmentarzu Srebrzysko, gdzie znajdują się groby ofiar katastrofy: Anny Walentynowicz, Leszka Solskiego i Arkadiusza Rybickiego, w Bazylice Mariackiej na Starym Mieście i w Dworze Artusa w Ratuszu Staromiejskim, gdzie odbyło się spotkanie Klubu Obywatelskiego „Pamięć, która łączy”, oraz Polskie Stronnictwo Ludowe, chociaż te uroczystości miały bardziej prywatny charakter (spotkanie z rodzinami posłów partii, którzy zginęli w Smoleńsku).

15 Tamże, s. 65-67; zob. też: M. Różycka, dz. cyt., s. 52-54.

${ }^{16} \mathrm{O}$ telewizyjnych trikach wykorzystywanych przez sztaby PR podczas debat wyborczych pisze m.in. Eryk Mistewicz (M. Karnowski, E. Mistewicz, Anatomia władzy. Mistewicz kontra Karnowski, Czerwone i Czarne, Warszawa 2010).

${ }^{17}$ Pasażerowie samolotu byli delegacją polską na uroczystości związane z obchodami 70. rocznicy zbrodni katyńskiej. W samolocie oprócz pary prezydenckiej byli wicemarszałkowie Sejmu i Senatu, grupa parlamentarzystów, dowódcy wszystkich sił zbrojnych RP, pracownicy kancelarii Prezydenta RP, szefowie instytucji państwowych, duchowni, przedstawiciele ministerstw, organizacji kombatanckich i społecznych oraz rodziny polskich oficerów zamordowanych w 1940 roku w Katyniu przez oficerów NKWD. 
Wybrałam materiał emitowany $\mathrm{w}$ telewizji informacyjnej, ponieważ wiadomości telewizyjne są, po pierwsze, głównym źródłem informacji dla większości ludzi, zwłaszcza informacji politycznych. Po drugie, o czym już w latach 80. XX wieku pisali Shanto Iyengar i Donald B. Kinder na podstawie przeprowadzonych przez siebie badań eksperymentalnych, telewizyjne wiadomości mają pewną moc zatrzymywania uwagi widza oraz określania kryteriów będących podstawą osądów ${ }^{18}$. Wiadomości telewizyjne, ukierunkowując uwagę widzów na pewne wydarzenia, ignorując przy tym pozostałe (agenda setting), wpływają w decydujący sposób na to, którym z problemów ludzie przypisują wagę, i mogą zmieniać standardy ocen wystawianych wydarzeniom i osobom publicznym. Są więc doskonałym narzędziem oddziaływania politycznego.

\section{Struktura programu}

Na początku trzeba zauważyć, że ramówka programu została tego dnia w całości podporządkowana państwowym obchodom rocznicy smoleńskiej. Część programów została zdjęta (np. „Głos mediów”), inne zmieniły swój charakter (program „Po przecinku”, zwykle publicystyczny, miał charakter rozmowy wspomnieniowej o jednej z ofiar wypadku - Januszu Krupskim, gościem programu była jego żona). W kilku miejscach w Warszawie (Krakowskie Przedmieście, Cmentarz Powązkowski, Cmentarz Bródnowski) oraz na Polskim Cmentarzu Wojennym w Katyniu i na lotnisku wojskowym w Smoleńsku - w miejscu katastrofy, telewizja miała swoich reporterów. Powstało też specjalne studio na Krakowskim Przedmieściu, w którym dziennikarka Edyta Lewandowska rozmawiała z zaproszonymi gośćmi (w analizowanym czasie było siedem wejść na żywo: o godz. 8.16, 11.15, 11.50, 14.17, 16.40, 18.14, 18.56). Wyjątkowo z Krakowskiego Przedmieścia emitowano również program „Minęła dwudziesta” (godz. 20.30, prowadzący Michał Rachoń). Ponadto na żywo transmitowano wybrane wydarzenia:

1) w całości dwie msze święte, o godz. 12.30 z Polskiego Cmentarza Wojennego w Katyniu; o godz. 19.00 z bazyliki archikatedralnej pw. Męczeństwa św. Jana Chrzciciela w Warszawie;

2) apel poległych pod Pałacem Prezydenckim (godz. 8.58);

3) złożenie kwiatów przez prezesa Prawa i Sprawiedliwości, Jarosława Kaczyńskiego, pod Pałacem Prezydenckim (godz. 9.06);

${ }^{18}$ I. Shanto, D.B. Kinder, News that Matters. Television and American Opinion, University of Chicago Press, Chicago 1987. 
4) odsłonięcie tablicy upamiętniającej prezydenta Lecha Kaczyńskiego przez Jarosława Kaczyńskiego na dziedzińcu Mazowieckiego Urzędu Wojewódzkiego, przemówienie Jarosława Kaczyńskiego (retransmisja, godz. 14.26);

5) odsłonięcie tablicy upamiętniającej minister rozwoju regionalnego Grażynę Gęsicką oraz przemówienie prezesa PiS Jarosława Kaczyńskiego (godz. 14.38);

6) marsz z portretami ofiar katastrofy na Krakowskim Przedmieściu (godz. 16.00);

7) odsłonięcie tablicy upamiętniającej katastrofę smoleńską w gmachu Ministerstwa Obrony Narodowej oraz przemówienie ministra obrony narodowej Antoniego Macierewicza (godz. 16.12);

8) odsłonięcie tablicy upamiętniającej prezydenta Lecha Kaczyńskiego oraz przemówienie prezydenta Andrzeja Dudy i Marty Kaczyńskiej, córki zmarłej pary prezydenckiej (godz. 17.10);

9) marsz pamięci na Krakowskim Przedmieściu (godz. 20.00);

10) wystąpienie prezesa PiS, Jarosława Kaczyńskiego, na Krakowskim Przedmieściu (godz. 21.12);

11) złożenie wieńców przez delegację polską w Smoleńsku oraz przemówienie Anny Marii Anders, przewodniczącej Rady Ochrony Pamięci Walk i Męczeństwa (godz. 15.25);

12) składanie kwiatów na grobach ofiar katastrofy przez premier Beatę Szydło i Jarosława Kaczyńskiego w Świątyni Opatrzności Bożej (godz. 9.50), na Cmentarzu Powązkowskim (godz. 11.30-12.00), przez prezydenta Andrzej Dudę w Świątyni Opatrzności Bożej (godz. 14.10) i na Cmentarzu Powązkowskim (godz. 14.25), przez polityków PiS na Cmentarzu Bródnowskim (godz. 11.07).

Takie zmiany w ramówce zawsze świadczą o wyjątkowej randze transmitowanych zdarzeń. Również wszystkie serwisy informacyjne TVP Info zostały poświęcone obchodom katastrofy. Natomiast już w tym miejscu należy podkreślić, że, jak widać na podstawie powyższego wyliczenia, mówiono tylko o państwowych (organizowanych przez PiS) obchodach katastrofy i transmitowano tylko te wydarzenia, w których uczestniczyli przedstawiciele władz państwowych (prezydent, premier, przedstawiciele rządu lub partii rządzącej).

\section{Temat globalny i tematy szczególowe}

Katastrofa smoleńska była tego dnia tematem globalnym stacji (wszystkich programów i serwisów informacyjnych). Poświęcono jej niemal 100 procent czasu antenowego. Informacje o innych wydarzeniach z kraju i ze świata emitowane były tylko w formie zwiastunów na pasku. Jeśli chodzi o tematy szczegółowe, realizowane w poszczególnych audycjach, były to: 
- wspomnienia o ofiarach katastrofy (sylwetki Janusza Krupskiego - rozmowa z jego żoną, Joanną Krupską; Pawła Stasiaka - rozmowa z jego żoną, Barbarą Stasiak);

- przyczyny katastrofy;

- śledztwo w sprawie katastrofy;

- odpowiedzialność za katastrofę;

- emocje związane z katastrofą obecnie i sześć lat temu;

- zbrodnia katyńska (rozmowa z prof. Zbigniewem Wawerem, dyrektorem Muzeum Wojska Polskiego, i Robertem Kostro, dyrektorem Muzeum Historii Polski) ${ }^{19}$.

\section{Bohaterowie wydarzeń}

Tego dnia TVP Info relacjonowała wydarzenia, w których uczestniczyły osoby związane z obozem rządzącym. Najczęściej na ekranie pojawiał się prezes PiS Jarosław Kaczyński, w drugiej kolejności - prezydent Andrzej Duda, w końcu - premier Beata Szydło. Ta ostatnia pokazywana była tylko w towarzystwie Jarosława Kaczyńskiego. Poniższe zestawienie pokazuje obecność na ekranie wymienionych polityków:

Tabela. 1. Obecność wybranych polityków na ekranie (w minutach)

\begin{tabular}{|l|c|c|c|}
\hline & Jarosław Kaczyński & Beata Szydło & Andrzej Duda \\
\hline Obecność na ekranie ogółem & $73^{\prime} 28^{\prime \prime}$ & $26^{\prime}$ & $32^{\prime} 03^{\prime \prime}$ \\
\hline $\begin{array}{l}\text { Oficjalne przemówienia } \\
\text { i komentarze dla mediów }\end{array}$ & $31^{\prime} 28^{\prime \prime}$ & $0^{\prime}$ & $30^{\prime} 43^{\prime \prime}$ \\
\hline $\begin{array}{l}\text { Składanie wieńców na } \\
\text { grobach ofiar katastrofy }\end{array}$ & $42^{\prime}$ & $26^{\prime}$ & $1^{\prime} 20^{\prime \prime}$ \\
\hline
\end{tabular}

Źródło: oprac. własne.

Jeśli chodzi o stosunek czasu antenowego poświęconego pokazywaniu aktywności przedstawicieli władzy w stosunku do aktywności członków opozycji, to wyraźnie faworyzowano władzę. Polityków opozycji można było tego dnia w TVP Info zobaczyć przez niecałe 30 sekund.

${ }^{19}$ Ten temat zajął w sumie 12 minut na 14 godzin programu w ogóle, co wyraźnie pokazuje skalę zainteresowania stacji oboma tematami. 
Tabela 2. Obecność na ekranie przedstawicieli władzy i opozycji (w minutach)

\begin{tabular}{|c|c|}
\hline Przedstawiciele władzy & Opozycja \\
\hline $121^{\prime} 31^{\prime \prime}$ & $0^{\prime} 30^{\prime \prime}$ \\
\hline
\end{tabular}

Źródło: oprac. własne.

Tendencyjny był też dobór gości do programów emitowanych tego dnia na antenie. Były to przede wszystkim osoby związane z obozem władzy - politycy PiS i dziennikarze mediów prawicowych: Barbara Stasiak (wdowa po Władysławie Stasiaku, szefie Kancelarii Prezydenta Kaczyńskiego), Małgorzata Gosiewska (posłanka PiS), Marcin Kierwiński (poseł PO), Wojciech Skurkiewicz (poseł PiS), Waldemar Pawlak (członek PSL), Piotr Apel (Kukiz'15), Paulina Hennig-Kloska (posłanka partii .Nowoczesna), Marek Magierowski (Kancelaria Prezydenta Dudy), Maria Przełomiec („Wprost”), Emanuelis Zingeris (poseł na sejm Republiki Litewskiej), Joanna Krupska (wdowa po Januszu Krupskim, m.in. kierowniku Urzędu ds. Kombatantów i Osób Represjonowanych), Eliza Olczyk („Wprost”), Piotr Zaręba („wSieci”), Sylwester Pruszkiewicz („Super Express”), Tomasz Pietryga („Rzeczpospolita”), Michał Karnowski (,wSieci” i portal wPolityce.pl), ks. Henryk Zieliński (tygodnik „Idziemy”), Dorota Kania („Gazeta Polska”), Ewa Stankiewicz (TV Republika i Stowarzyszenie Solidarni 2010), Jadwiga Wiśniewska (europosłanka PiS), Anita Gargas (TV Republika), Barbara Fedyszak-Radziejowska (członkini rady programowej PiS), Michał Kleiber (Polska Akademia Nauk), Henryk Domański (Polska Akademia Nauk), Ryszard Legutko (europoseł PiS), Antoni Macierewicz (poseł PiS, minister obrony narodowej).

Dobór interlokutorów niewątpliwie ułatwiał dziennikarzom odpowiednie ramowanie rozmów.

\section{Serwis informacyjny - gatekeeping, ramowanie, manipulowanie emocjami}

Na podstawie jednego z wyemitowanych tego dnia serwisów informacyjnych chciałabym pokazać wykorzystywane przez dziennikarzy TVP Info techniki manipulowania treścią przekazu. Mówiąc o manipulacji, myślę o takich działaniach językowych i pozajęzykowych, których celem jest oddziaływanie na wiedzę, sposób myślenia i działania odbiorcy, ale przy założeniu, że nie ma on świadomości stosowanych przez nadawcę zabiegów. Nie można tu zatem mówić o sytuacji równorzędności uczestników aktu komunikacji - pozycja nadawcy jest nadrzędna. Nieświadomość odbiorcy pozwala na traktowanie go instrumentalnie i przedmiotowo ${ }^{20}$.

${ }^{20}$ J. Bralczyk, Manipulacja językowa, [w:] Dziennikarstwo i świat mediów, red. Z. Bauer, E. Chudziński, Universitas, Kraków 2000, s. 244. 
Tabela 3. Fragmenty serwisu informacyjnego z godz. 11.33, prowadzący Michał Cholewiński

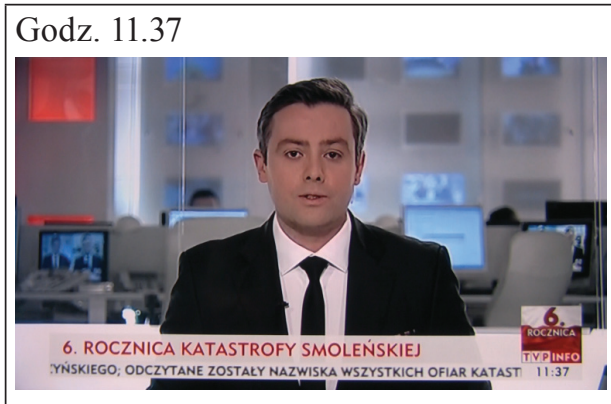

„Biała”21:

Przez caty dzień w TVP Info będa mieli Państwo okazję zobaczyć wszystko, co upamiętnia, wszystko, co podkreśla, że Polska sześć lat temu straciła dziewięćdziesięcioro sześcioro rodaków. Przed pomnikiem ofiar katastrofy smoleńskiej na Cmentarzu Powazkowskim od rana uroczystości organizowane między innymi przez władze stolicy.

Zaimek upowszechniający „wszystko” implikuje, że stacja pokazuje to, co się dzieje, bez wyjątku, natomiast jeśli o czymś nie mówi, czegoś nie pokazuje, to znaczy, że tego nie było. Jest to implikatura ważka w kontekście tego, co już zostało pokazane w analizie ilościowej, a mianowicie ogromnej dysproporcji w relacjonowaniu aktywności władzy w stosunku do przedstawicieli innych partii. Na jej podstawie widz, oglądając przez cały dzień tylko polityków partii rządzącej, wyciąga wniosek, że tylko oni oddawali cześć ofiarom.

Godz. 11.37-11.43
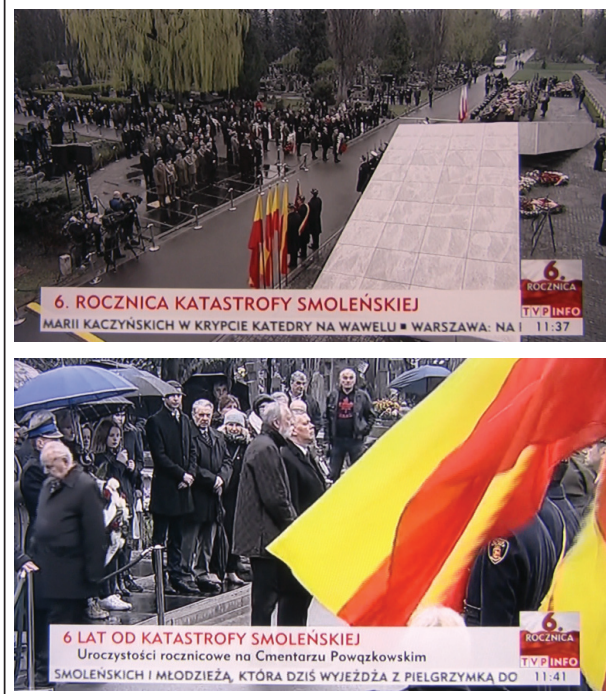

Retransmisja fragmentu uroczystości

z Cmentarza Wojskowego na Powązkach w Warszawie. Zdjęcia delegacji składających wieńce pod pomnikiem ofiar katastrofy smoleńskiej; dźwięk oryginalny.

21 „Biała” i „zielona” to określenie z żargonu dziennikarskiego. „Biała” oznacza tekst odczytywany przez prezentera w studiu (nazwa pochodzi od białej kartki maszynopisu lub wydruku komputerowego, na której znajduje się taki tekst), „zielona” - tekst mówiony z offu (zapisany na zielonej kartce). 


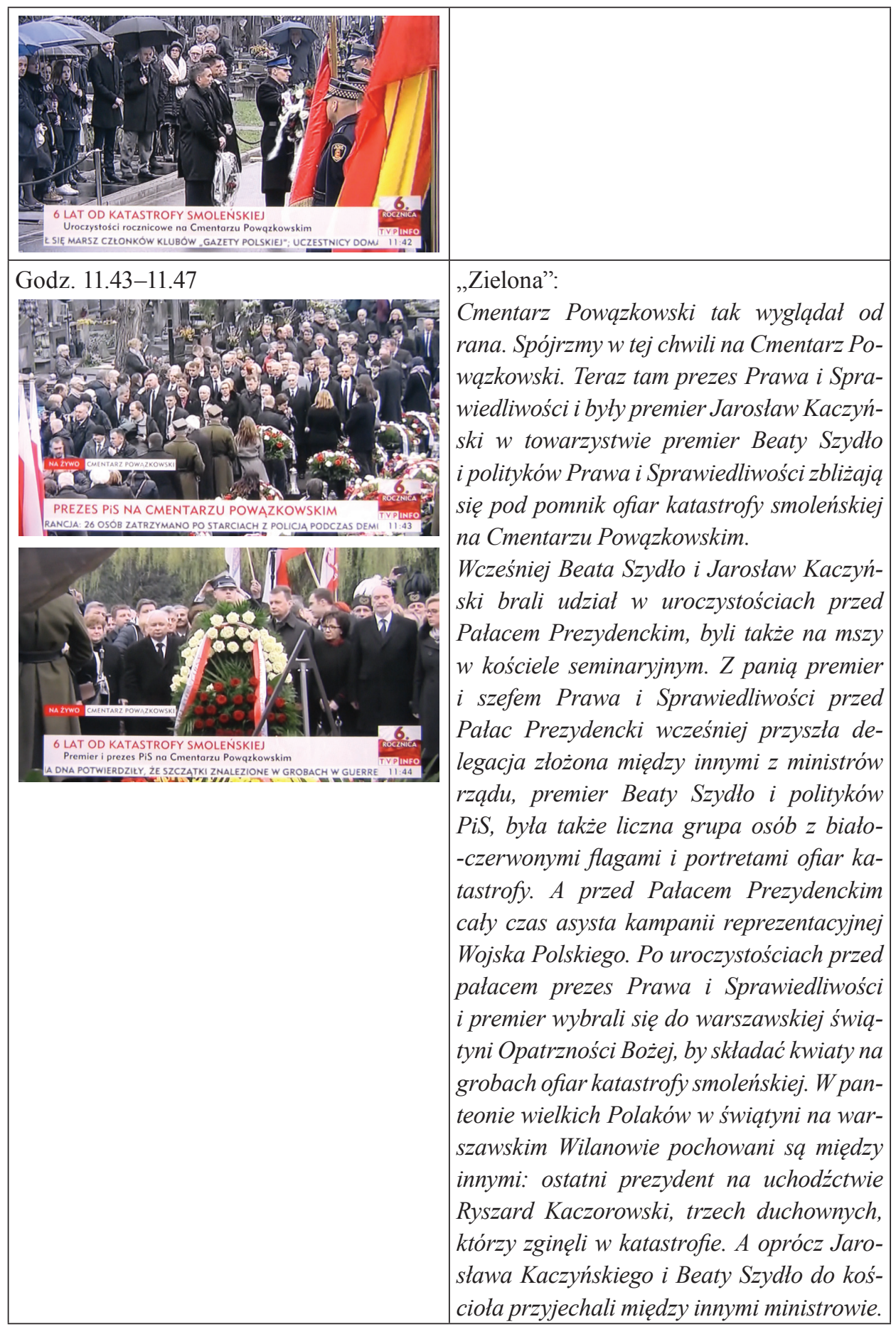




\begin{tabular}{|l|l|}
\hline & $\begin{array}{l}\text { W tej chwili obserwujemy ten fragment } \\
\text { uroczystości, podczas której lider Prawa } \\
\text { i Sprawiedliwości, premier polskiego rza- } \\
\text { du upamiętniaja ofiary katastrofy lotniczej } \\
\text { pod Smoleńskiem na cmentarzu wojsko- } \\
\text { wym na warszawskich Powazkach. }\end{array}$ \\
\hline $\begin{array}{l}\text { Nadawca przemilcza część informacji dotyczących złożenia wieńców przy pomniku } \\
\text { ofiar katastrofy - nie wymienia nazwisk polityków, którzy uczestniczą w tych uro- } \\
\text { czystościach, jeśli nie są to politycy Prawa i Sprawiedliwości. Tylko uważny widz był } \\
\text { w stanie na cmentarzu w tłumie delegacji rozpoznać twarze przynajmniej dwóch po- } \\
\text { lityków opozycji - Ryszarda Petru z Nowoczesnej i Rafała Grupińskiego z Platformy } \\
\text { Obywatelskiej. Byli oni pokazywani w planie pełnym, bez zbliżeń, przez około 15 se- } \\
\text { kund każdy. Jednocześnie siedmiokrotnie w tak krótkiej wypowiedzi powtórzone zo- } \\
\text { stają nazwiska i/lub tytuły prezesa PiS i premier Beaty Szydło. W tym dwukrotnie } \\
\text { powtórzono informację o tym, że składają oni wieńce na Cmentarzu Powązkowskim, } \\
\text { co (w transmisji na żywo) pokazywane jest na ekranie. Mamy tutaj do czynienia z tzw. } \\
\text { komentarzem²2 równoległym, który powtarza to, co na obrazie i kieruje uwagę widza } \\
\text { na to, co powinien on zobaczyć i zapamiętać. Warto podkreślić, że Jarosław Kaczyński } \\
\text { i Beata Szydło pokazywani są w planach amerykańskim i średnim, a także w pół- } \\
\text { zbliżeniach. Są to plany, które nie tylko pozwalają rozpoznać postaci występujące na } \\
\text { ujęciach, ale pełnią też funkcję perswazyjną - budzą emocje, w przeciwieństwie do } \\
\text { planów dalekich, które pozostawiają widza obojętnym, służą raczej do budowania kon- } \\
\text { tekstu²3. Trzecim kanałem informacji (obok słowa mówionego i obrazu) jest w telewizji } \\
\text { słowo pisane - tekst na ekranie. W analizowanym materiale wszystkim zdjęciom towa- } \\
\text { rzyszą następujące podpisy na belce: PREZES PIS NA CMENTARZU POWĄZKOW- } \\
\text { SKIM; } 6 \text { LAT OD KATASTROFY Premier i prezes PiS na Cmentarzu Powązkowskim; } \\
6 \text { LAT OD KATASTROFY SMOLENSKIEJ Premier, ministrowie oraz prezes PiS na } \\
\text { Cmentarzu Powązkowskim. Ta redundancja ma funkcję perswazyjną - ujednoznacznia } \\
\text { przekaz (nie ma wątpliwości co do zdarzeń) i go utrwala. }\end{array}$ \\
\hline
\end{tabular}

22 Słowo „komentarz” występuje tutaj w znaczeniu: ‘tekst komentujący obraz'.

${ }^{23} \mathrm{Na}$ temat funkcji planów w newsie telewizyjnym pisał np. K. Żórawski, Dlugi stót. Skrypt dla dziennikarzy pro-gramów informacyjnych, Telewizja Polska S.A., Warszawa 2004, s. 40-47. 


\begin{tabular}{|c|c|}
\hline Godz. 11.47 & $\begin{array}{l}\text { „Biała”: } \\
\text { Szósty raz uroczystości upamiętniajace } \\
\text { tych, którzy zginęli pod Smoleńskiem sa } \\
\text { już nierozerwalnie związane z uroczystoś- } \\
\text { ciami upamiętniajacymi naszych rodaków. } \\
\text { Ponad dwadzieścia tysięcy policjantów, } \\
\text { żołnierzy, pocztowców, urzędników pań- } \\
\text { stwowych, którzy zostali zgładzeni przez } \\
\text { bolszewików w tysiąc dziewięćset czter- } \\
\text { dziestym roku, między innymi w lesie ka- } \\
\text { tyńskim. Tam już jest polska delegacja. } \\
\text { Później będzie w Smoleńsku. Czas zatem } \\
\text { na obserwacjęz przebiegu tej uroczystości } \\
\text { od Marcina Czapskiego. }\end{array}$ \\
\hline \multicolumn{2}{|c|}{ Godz. 11.47-11.49 Relacja Marcina Czapskiego z lasu katyńskiego } \\
\hline Godz & $\begin{array}{l}\text { „Zielona”: } \\
\text { Dziękujemy za relację, czas zatem na } \\
\text { Cmentarz Powąkowski. Ponownie je- } \\
\text { steśmy przed pomnikiem ofiar katastrofy } \\
\text { smoleńskiej. Na Cmentarzu Powązkow- } \\
\text { skim kwiaty złożyli i Prezes Prawa i Spra- } \\
\text { wiedliwości i były premier, i szefowa rzadu } \\
\text { Beata Szydło. }\end{array}$ \\
\hline $\begin{array}{l}\text { OBCHODY } 6 . R O \\
\text { RANNY MARIIANDERS }\end{array}$ & $\begin{array}{l}\text { „Biała”: } \\
\text { Cmentarz Powązowski w Warszawie. } \\
\text { Jeszcze dziś będa mieli państwo okazję } \\
\text { spoglądać na to, kto w ten sposób czci pa- } \\
\text { mięć, honoruje tych, którzy stracili życie, } \\
\text { a także współdzieli ten ból, który przynio- } \\
\text { sta ta katastrofa wszystkim Polakom. Ten } \\
\text { ból jest też udziałem gości Edyty Lewan- } \\
\text { dowskiej, od rana w naszym plenerowym } \\
\text { studiu przed Pałacem Prezydenckim. }\end{array}$ \\
\hline & $\begin{array}{l}\text { edź, której implikatura brzmi: tylko ci, któ- } \\
\text { m katastrofy. Jest to manipulacja oparta na }\end{array}$ \\
\hline
\end{tabular}




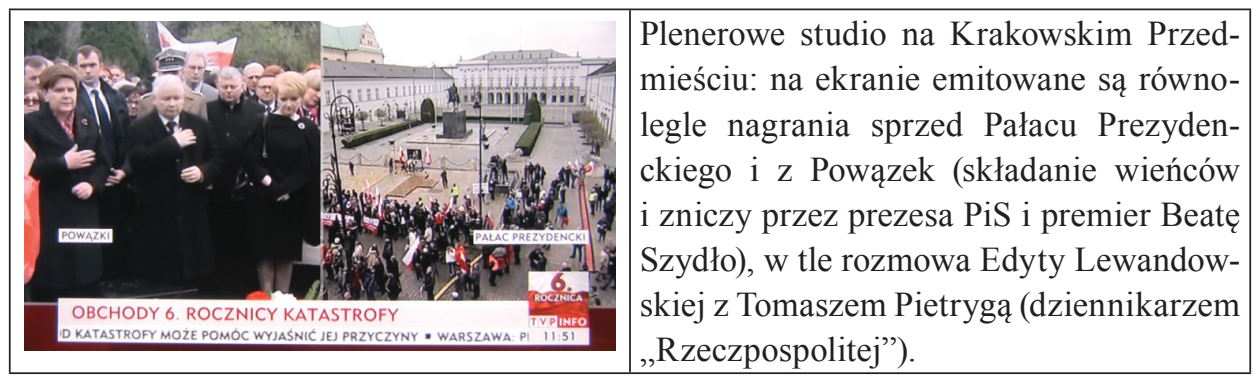

Źródło: oprac. własne.

Jeszcze jeden przykład (Tab. 4) - połączenie na żywo z reporterką Agatą Biały znajdującą się na Cmentarzu Powązkowskim:

Tabela 4. Połączenie na żywo z reporterką Agatą Biały

\begin{tabular}{|c|c|}
\hline Godz. 14.36 & $\begin{array}{l}\text { „Biała”: } \\
\text { Szósta rocznica katastrofy smoleńskiej, } \\
\text { siedemdziesiata szósta mordu katyńskiego. } \\
\text { To wszystko na bieżaco i cały czas w TVP } \\
\text { Info. [...] I Powazki, miejsce symboliczne, } \\
\text { nie tylko ze względu na pomnik, nie tylko } \\
\text { ze względu na cała wymowę uroczystości, } \\
\text { które od rana obserwujemy na Powązkach. } \\
\text { To jest miejsce, w którym nasza reporterka } \\
\text { Agata Biały o tym, jak wyglada ten dzień } \\
\text { od rana i kto uczcit pamięć tych, którzy } \\
\text { zginęli w Smoleńsku? }\end{array}$ \\
\hline $\begin{array}{l}\text { HI } \\
\text { HOLD DLA OFI } \\
\text { HOWI KACZYNSSKEM }\end{array}$ & $\begin{array}{l}\text { Relacja reporterska, z Powązek na żywo } \\
\text { Agata Biały: } \\
\text { No to faktycznie wyjątkowe miejsce, dzień } \\
\text { pełen zadumy i pełen nostalgii, jak się na } \\
\text { to spojrzy z perspektywy już tych kilkuna- } \\
\text { stu godzin. Tutaj te oficjalne uroczystości } \\
\text { odbyty się o poranku, bo między godzina } \\
\text { ósma dwadzieścia a ósma czterdzieści } \\
\text { dwa, kiedy to uroczystości oficjalnie już za- } \\
\text { kończono, ale to zdecydowanie nie byt ko- } \\
\text { niec. Patrząc na te najnowsze informacje, } \\
\text { to prezydent Andrzej Duda na Powazkach } \\
\text { byt po godzinie trzynastej dziesięć się po- } \\
\text { jawit. Ztożyt wieńce na każdym z grobów, } \\
\text { który obokpomnika katastrofy smoleńskiej }\end{array}$ \\
\hline
\end{tabular}




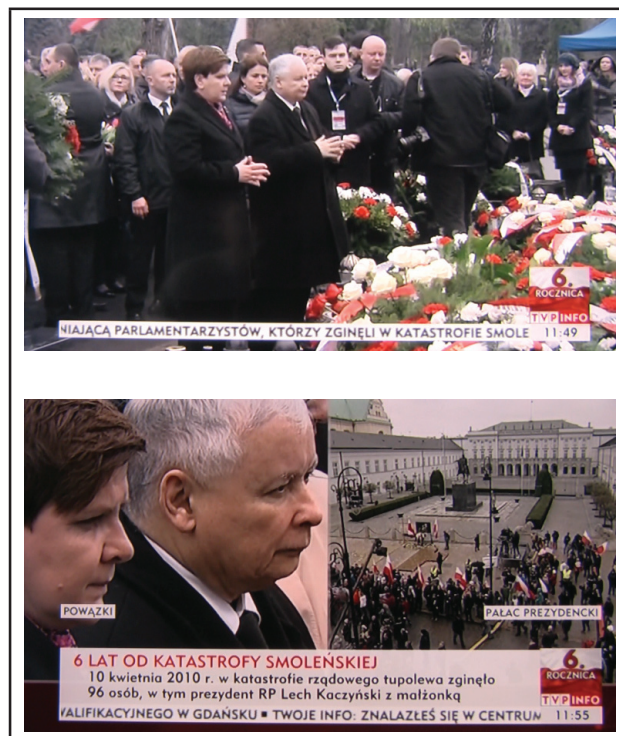

jest. Wcześniej Beata Szydło oraz byly premier Jarosław Kaczyński złożyli kwiaty, zapalili znicze na wszystkich tutaj obecnych grobach. Byli również marszatkowie Sejmu, marszatek Senatu. Byli również ministrowie, bo minister sprawiedliwości, minister spraw zagranicznych, czy minister Błaszczak tutaj na warszawskich Powazkach się pojawit. I jeszcze wcześniej te oficjalne wizyty. Czyli wizyta władz państwowych, przedstawiciele władz samorzadowych, ale przede wszystkim rodzin ofiar katastrofy smoleńskiej. Była tu między innymi minister Beata Kempa, była Hanna Gronkiewicz-Waltz i modlitwa ekumeniczna tutaj miała miejsce. [...] Jeżeli chodzi o to, kto tu byt. Tu przede wszystkim byli Polacy. Byli Polacy mimo niesprzyjajacej pogody, naprawde thum nie tylko warszawiaków, ale Polaków na warszawskich Powazkach się pojawit. Teraz Powazki tona w biało-czerwonych kwiatach, no i zniczach.

Po raz kolejny w cytowanej wypowiedzi mamy do czynienia z przemilczeniem. Informacja o uroczystościach organizowanych przez prezydent miasta Hannę Gronkiewicz-Waltz (związaną z Platformą Obywatelską), w których uczestniczyły delegacje różnych organizacji i partii politycznych, jest bardzo lakoniczna - dziennikarka nie mówi, kto brał udział w uroczystości, ani co się działo. Słyszymy tylko: „Tutaj te oficjalne uroczystości odbyły się o poranku, bo między godziną 8.20 a 8.42”. I tak, jak we wcześniej analizowanym fragmencie - temu przemilczeniu towarzyszy wyeksponowanie aktywności strony rządzącej. W tym przypadku dziennikarka szczegółowo wymienia wszystkich polityków. Są oni też pokazywani na ekranie.

Źródło: oprac. własne.

Widoczna jest bardzo wyraźna różnica w sposobie informowania o aktywności przedstawicieli rządu i partii rządzącej oraz partii opozycyjnych. Do manipulacji zastosowano technikę gatekeepingu - selekcji informacji. Nadawca przekazuje odbiorcy informacje niepełne, przemilczające część wiadomości lub nie informuje o czymś w ogóle. PSL i PO również organizowały uroczystości upamiętniające ofiary katastrofy, ale przez czternaście godzin programu nie poinformowano o tym ani razu. Działa tutaj „mechanizm czynienia rzeczywistości”, a więc powoływania do życia pewnych idei, wydarzeń i opinii i odsyłanie w nie- 
byt innych ${ }^{24}$. Prezentowane jest tylko to, co służy celowi, na rzecz którego prowadzi się argumentowanie, w tym przypadku jest to promowanie władzy i partii rządzącej.

Drugą techniką manipulacji jest ramowanie (framing). Jak już wspomniałam, sprzyja mu dobór gości zaproszonych do poszczególnych audycji. Ramowanie to proces selekcji perspektywy dla obrazu sytuacji, a następnie wyrażenie go w określonym ujęciu. Rama interpretacji, podobnie jak kadr filmu, narzuca kierunek oglądu i sposób rozumienia sytuacji. W kadrze filmu ujęte jest tylko to, czego sobie życzymy i w taki sposób, na jaki pozwala nam aparatura ${ }^{25}$. W telewizji ramowanie jest procesem kontroli nad zawartością przekazu, określa sposób prezentacji treści, wyłaniając pożądane interpretacje, a pomijając inne, w celu nadania im szczególnej wagi, zazwyczaj dla propagowania pewnej idei, poglądu czy oceny. Decydujące jest tutaj znalezienie tematów, słów kluczy, haseł, które stworzą ramy dyskursu i jednoznacznie ustawią relacje i skojarzenia. Słowa używane przez dziennikarzy opisują prezentowane tematy, tym samym ustalając, w jaki sposób widz ma rozumieć to, co pojawia się na ekranie. Interesują mnie przede wszystkim wypowiedzi redaktorów (i tylko te cytuję), ponieważ to oni decydują o przebiegu rozmowy i wyznaczają jej tematykę. Selekcja rozmówców pozwoliła dość łatwo narzucić perspektywę oglądu problemu katastrofy smoleńskiej. Jest to pespektywa odwołująca się do interpretacji znanej z narracji PiS. Zaproszeni do rozmów goście poruszali się wokół tez formułowanych przez dziennikarzy. Te tezy to:

1) Nie wiemy, co wydarzyło się w Smoleńsku, przyczyny katastrofy nie zostały wyjaśnione:

Edyta Lewandowska: Zadam pytanie, które styszała Pani na pewno mnóstwo razy i to pytanie zadaja sobie Polacy, i to jest pytanie, które odbija się echem bez przerwy, jak daleko jesteśmy od wyjaśnienia przyczyn tej katastrofy?

Michał Rachoń: Czy faktycznie jest tak, że nie ma w tej chwili woli, żeby dotrzeć do prawdy?

Michał Rachoń: W przemówieniu Jarosława Kaczyńskiego byta mowa o trzech perspektywach. O perspektywie pamięci, faktów i sprawiedliwości. A mowa była dzisiaj również o przebaczeniu. W jaki sposób mówić o przebaczeniu bez pewności co do faktów na temat Smolenska?

${ }^{24}$ P. Nowak, Retoryka a propaganda polityczna, [w:] Retoryka, red. M. Barłowska, A. Budzyńska-Daca, P. Wilczek, Wydawnictwo Naukowe PWN, Warszawa 2008, s. 211.

25 J. Wasilewski, A. Skibiński, Prowadzeni stowami. Retoryka motywacji w komunikacji publicznej, Wydawnictwo Difin, Warszawa 2008, s. 41. 
Edyta Lewandowska: W jaki sposób w tej chwili, po sześciu latach, ta wciąż niewyjaśniona tragedia pod Smoleńskiem jest odbierana na Wschodzie?

Edyta Lewandowska: Z czego wynika opór przeciwko przeprowadzeniu niektórych bardzo ważnych dowodów? Czy to jest tylko zaniechanie czy w pani ocenie jakieś świadome działanie?

Edyta Lewandowska: Czy jest pani przekonana o tym, że uda nam się dojść do prawdy, przeprowadzić wszystkie dowody i istotnie wyjaśnić, co wydarzyło się 10 kwietnia 2010 roku, i ile to może potrwać w pani ocenie?

W tym kontekście pojawił się w dwu programach („,Po przecinku” i ,Minęła dwudziesta”) wątek współodpowiedzialności środowiska naukowego za niewyjaśnienie przyczyn katastrofy smoleńskiej:

Michał Rachoń: Ja pytam $w$ gruncie rzeczy o to, z jakich powodów instytucje $i$ to nie instytucje polityczne, bo przecież środowiska naukowe sa pozbawione, a przynajmniej powinny być pozbawione tego elementu sporu politycznego, o którym pan mówi, nie zdecydowaty się na to, żeby instytucjonalnie wziąć udział w próbie odpowiedzi na pytanie, co się stało?

Michał Rachoń: Zjakiego powodu świat nauki instytucjonalnie nie chciat się tą sprawa zająć?

Michał Rachoń: Czy pania, tak po ludzku, nie zastanawia, dlaczego świat nauki zdecydowat nie zajmować się tym tematem?

Michał Rachoń: Nie ma najmniejszych wątpliwości, że konferencja naukowa, która została zorganizowana w tym celu, w której komitecie organizacyjnym nie ma ani jednego polityka, zgłosiła się do wszystkich politechnik w Polsce z prośbą o wsparcie w tej sprawie $i$ żadna z polskich politechnik nie zgodziła się, aby w jakikolwiek sposób włączyć się w tę sprawę. Moje pytanie brzmi, dlaczego?

Michał Rachoń: Polskie instytucje nauki, żadna z polskich instytucji badawczych, żadna z uczelni, z politechnik, nie chciała się w to właczyć instytucjonalnie. Jak Pan to interpretuje, dlaczego tak się stało? I czy to nie jest jednak wyrzut sumienia świata polskiej nauki?

Michał Rachoń: Jeśli instytucjonalna nauka nie zareagowała, no to nie możemy się dziwić temu, że podział społeczny, o których mówiła pani doktor, czy pan profesor, istnieje. No bo skąd ludzie maja wiedzieć, jaki byt przebieg wydarzeń, jeżeli świat nauki nie jest $w$ stanie odpowiedzieć na to pytanie? 
2) Państwo polskie dotąd nie upamiętniło ofiar katastrofy smoleńskiej:

Michał Rachoń: Jak mamy upamiętnić tych ludzi? Państwo powinno zadbać o to, by pamięć o tych ludziach była.

Michał Rachoń: W jaki sposób w przestrzeni publicznej upamiętnić to zdarzenie? Pomnik smoleński jest ciagle przedmiotem dyskusji i sporu. Dlaczego? Ja bym chciat, żeby stanąt w centrum Warszawy pomnik, który upamiętnia tę sprawę.

3) Naród polski był monolitem, który po katastrofie smoleńskiej został rozbity:

Edyta Lewandowska: Mówiliśmy tutaj o tym, że mieliśmy wtedy poczucie takiej wspólnoty, że czuliśmy, że jesteśmy jednym narodem. Tak, jak dawno tego nie odczuwaliśmy i nagle, po kilku dniach zaczęło się dziać coś, co spolaryzowało społeczeństwo.

Odpowiednie ramowanie prowadzi do tego, że konstruowany przekaz staje się apologią aktualnej władzy. Jest to pochwała - przez kontrast do władzy poprzedniej, która jest wartościowana negatywnie. Przypisuje się jej złe intencje, dziennikarze w swoich pytaniach prowokują do negatywnych ocen, np.

Edyta Lewandowska: I być może, gdyby wtedy [bezpośrednio po katastrofie - B.S.] zostały podjęte takie decyzje, na które wszyscy czekali, to tatwiej byłoby się z ta sprawa wszystkim uporać.

Z wypowiedzi gości wybierane są jednoznacznie negatywne oceny, które, by wzmocnić ich perswazyjność, eksponowane są na pasku, np.

Ewa Stankiewicz: Donald Tusk zgodził się na rezygnację Polski o dochodzenie do prawdy ws. katastrofy smoleńskiej.

EWA STANKIEWICZ: DONALD TUSK POWINIEN PONIEŚĆ NAJWYŻSZĄ KARĘ ZA SWOJE ZACHOWANIE ${ }^{26}$.

Z drugiej strony mamy jawne wartościowanie pozytywne obecnej władzy. Na poziomie werbalnym i poprzez obraz. Podkreśla się aktywność władzy, ale także pokazuje się premier Szydło, prezesa PiS, prezydenta, polityków PiS, ministrów rządu w korzystnych wizerunkowo kontekstach: w bardzo uroczystych

${ }^{26}$ Wykorzystanie w zapisie wersalików również ma funkcję perswazyjną. Tekst zapisany dużymi literami uznajemy za ważniejszy. Warto w tym miejscu przypomnieć, że na przykład w netykiecie tekst zapisany dużymi literami interpretuje się jako krzyk. 
sytuacjach oficjalnych, gdy składają hołd ofiarom, przewodzą marszom, ale też w sytuacjach bardzo prywatnych - gdy się modlą (w kościele, przy nagrobkach, w miejscach pamięci). Pokazywanie osób publicznych w sytuacjach prywatnych służy ocieplaniu wizerunku. Poza tym, prezentowanie przedstawicieli władzy w kontekstach religijnych ma dodatkowe znaczenie - wzmacnia ich wiarygodność w oczach tej części odbiorców, którym bliskie jest myślenie w kategoriach religijnych.

Znamienne jest rozbudowanie w wypowiedziach reporterów i dziennikarzy form grzecznościowych wartościujących pozytywnie postaci, do których się odnoszą, służących identyfikacji sprzymierzeńców politycznych ${ }^{27}, \mathrm{np}$. w informacjach o prezydencie Kaczyńskim dziennikarze powtarzali frazę tytularną uwzględniającą również jego tytuł naukowy, a zatem mowa była o „prezydencie profesorze Lechu Kaczyńskim”. Celem tego zabiegu było podniesienie prestiżu społecznego prezydenta. Jarosław Kaczyński natomiast bardzo konsekwentnie tytułowany był ,premierem”, np.

Adrian Klarenbach: Między 16.50 a 17.00 będzie miało miejsce odstonięcie na froncie pałacu prezydenckiego tablicy upamiętniajacej profesora prezydenta Lecha Kaczyńskiego. Ta uroczystość odbędzie się z udziatem obecnie urzędującego prezydenta Andrzeja Dudy, a także bylego premiera, a obecnie prezesa PiS Jarostawa Kaczyńskiego. Następnie około godziny 21.00 spodziewamy się tu, przed Pałacem Prezydenckim, wystapienia samego prezesa PiS Jarosława Kaczyńskiego (serwis informacyjny, godz. 10.30).

Adrian Klarenbach: Wydarzenia odbywaja się w wielu miejscach Warszawy, sa odstaniane tablice pamiatkowe, $w$ tym miejscu nastapi odstonięcie tablicy poświęconej profesorowi prezydentowi Lechowi Kaczyńskiemu. [...] w uroczystościach udziat wezma prezydent Andrzej Duda, premier Beata Szydto, prezes Jarosław Kaczyński, równiė̇ byly premier (serwis informacyjny, godz. 11.33).

Elżbieta Żywioł: Około godziny 13.00 tablicę upamiętniająca profesora Lecha Kaczyńskiego odstoni także jego brat Jarosław Kaczyński (serwis informacyjny, godz. 12.05) [podkreśl. B.S.].

Jednocześnie dziennikarze pomijali tytulaturę, gdy mówili o tych, których rząd nie popiera. Były premier Donald Tusk był po prostu Donaldem Tuskiem, prezydent Warszawy to po prostu Hanna Gronkiewicz-Waltz. Dzięki temu odbiorca zapamiętuje pozytywny charakter „swojego” i negatywny „obcego”.

${ }^{27} \mathrm{O}$ używaniu nazw własnych w języku propagandy politycznej pisał Paweł Nowak. Zob. P. Nowak, Retoryka a propaganda polityczna, dz. cyt., s. 214-215. 
Kilkakrotnie wspominałam o obrazie i sposobie kadrowania. Audiowizualna forma przekazu telewizyjnego pozwala na zbudowanie w widzu przekonania, że nie tylko jest on poinformowany o tym, co dzieje się w świecie, ale też, że obserwuje rzeczywistość i uczestniczy w zdarzeniach, do których nie ma fizycznego dostępu. Obraz ma bowiem, jak mówi Pierre Bourdieu, szczególną zdolność wytwarzania „efektu rzeczywistości” ${ }^{28}$. Telewizja sprawia, że ludzie widzą coś i wierzą $w$ to, co ona pokazuje. Obrazy z miejsca zdarzeń i relacje na żywo, wywołując poczucie naoczności, pełnią więc funkcję uwiarygodniającą. Ale są też ważnym narzędziem emocjonalizacji przekazu - była już mowa o tym, że im plan jest ogólniejszy, tym „temperatura przekazu” jest niższa. Budowaniu emocji natomiast sprzyjają plany bliskie. W końcu, obrazy telewizyjne służą promowaniu osób lub grup ludzi ${ }^{29}$. W analizowanym materiale są to: Jarosław Kaczyński (o czym niewątpliwie świadczy czas jego obecności na ekranie) oraz Lech Kaczyński. W ciągu dnia sześciokrotnie wyemitowano spoty przypominające wydarzenia z 10 kwietnia 2010 roku i dni następnych oraz postaci Lecha i Marii Kaczyńskich. Wykorzystano w nich zdjęcia, które w polskich mediach nabrały już znaczeń symbolicznych: wylatujący z Polski samolot, wrak samolotu w miejscu katastrofy, tłum ludzi na Krakowskim Przedmieściu składający kwiaty i znicze pod Pałacem Prezydenckim, Wawel w dniu pogrzebu pary prezydenckiej, przywożone do Polski trumny, kondukty żałobne ${ }^{30}$. Powtarzanie tych samych zdjęć i spotów może rodzić zjawiska ujemne - znudzenie i irytację odbiorcy, ale można je uznać za jeden z podstawowych warunków skuteczności w działaniach perswazyjnych, biorąc pod uwagę to, że ludzka percepcja jest wybiórcza i już na etapie rejestracji wrażeń i obiektów ze świata zewnętrznego dokonujemy selekcji informacji, część z nich eliminując, a potem tracimy informacje jeszcze na etapie interpretowania i zapamiętywania ${ }^{31}$.

Budowaniu emocji w analizowanym materiale służyło też pokazywanie tłumów. Zdjęcia zbiorowości, ludzi zmierzających razem, wspólnie manifestujących, wspólnie wykonujących jakieś czynności również mają funkcję perswazyjną,

${ }^{28}$ P. Bourdieu, O telewizji. Panowanie dziennikarstwa, przeł. K. Sztandar-Sztanderska, A. Ziółkowska, red. M. Jacyno, Wydawnictwo Naukowe PWN, Warszawa 2009, s. 47.

${ }^{29}$ Duże znaczenie przywiązywano do przedstawień przywódców politycznych w reżimach totalitarnych, w których powstawały specjalne portrety wodzów (w ZSRR, Korei Płn., w III Rzeszy). Ukazywano przywódców zawsze jako sprawnych fizycznie, ukrywano natomiast ich fizyczne mankamenty (np. laskę Adolfa Hitlera, ślady po ospie u Stalina). Dzisiaj również manipuluje się w ten sposób wizerunkami polityków. Przykładem są chociażby medialne przedstawienia prezydentów amerykańskich czy Władimira Putina.

${ }^{30}$ Nie bez znaczenia był też podkład muzyczny - poruszający motyw z utworu Michała Lorenca Powrót do domu, rozpięty między tonacją a-moll - uznawaną za żałosną, zapraszającą do snu, $\mathrm{a}$ - kojarzoną z motywami religijnymi - tonacją d-moll.

${ }^{31}$ R.J. Strenberg, Psychologia poznawcza, przeł. E. Czerniawska, A. Matczak, Warszawa 2001, s. $203-219$. 
służą konsolidacji wspólnoty i wzmocnieniu wewnętrznej tożsamości. Tłum ludzi gromadzących się pod Pałacem Prezydenckim był motywem przewodnim przekazu TVP Info. W sumie tego dnia przez 141 minut i 22 sekundy stacja pokazywała tłum - w planie ogólnym, ale też w planie średnim, aby zobrazować emocje ludzi w grupie. By ujednoznacznić przekaz, dziennikarze również o tych emocjach mówili:

Adrian Klarenbach: [...] atmosfera tutaj na Krakowskim Przedmieściu dziś jest zupetnie inna od tej, która panowała przez sześcioma laty. Wtedy smutek, żal, gorycz, rozgoryczenie, niedowierzanie przede wszystkim. Dziś mamy świadomość tego, mamy - mówię w imieniu wszystkich tych, którzy na Krakowskim Przedmieściu już sa, jak również w imieniu tych wszystkich, którzy na Krakowskim Przedmieściu dopiero się pokaża, mamy świadomość tych wydarzeń i tego, co się stato. Dziś ludzie serdecznie, z uśmiechami czekają, przychodzq, chca oddać cześć temu, co wydarzyto się przed sześcioma laty, a temu między innymi ma stużyć wydarzenie, które będzie miało miejsce tutaj w tym miejscu mniej więcej w okolicach godziny siedemnastej. (serwis informacyjny, godz. 14.10) [podkreśl. - B.S.].

W kontekście propagandy politycznej, by obraz był skutecznym narzędziem perswazji, często wymaga interpretacji. Nadawca musi mieć pewność, że odbiorca we właściwy sposób odczyta jego intencje. Słowa stają się narzędziem wykorzystywanym do dopowiedzenia, zracjonalizowania czy uwznioślenia obrazu ${ }^{32}$ i z takim zabiegiem mamy często do czynienia w analizowanym materiale. Ważne są nie tylko komentarze reporterskie, ale również - o czym była już mowa - podpisy.

\section{Dlaczego telewizja?}

Przedstawiona analiza pokazuje tylko część środków, którymi dysponuje nadawca telewizyjny, konstruując przekaz propagandowy, zjakim mamy do czynienia w tym przypadku. Nadawca wykorzystał określone metody perswazji i manipulacji w celu kształtowania świadomości odbiorców zgodnie z interesami określonego podmiotu politycznego - partii rządzącej. Celem nadrzędnym było promowanie władzy i partii rządzącej. Na to, że telewizja uznawana jest za najpotężniejszy instrument kształtowania opinii, a tym samym doskonałe narzędzie oddziaływania politycznego, wpływ mają oprócz wymienionych metod także inne czynniki.

${ }^{32}$ R. Barthes, The Responsibility of Forms. Critical Essays on Music, Art, and Representation, Hill and Wang, New York 1985, s. 14-16. 
Po pierwsze - zasięg. Odbiornik telewizyjny jest dobrem powszechnym, a ludzie, według najnowszych badań przeprowadzonych przez Nielsen Audience Measurement, spędzają przed telewizorem ponad 30 godzin tygodniowo - Polacy średnio 4 godziny i 23 minuty dziennie ${ }^{33}$. Ponad połowa badanych $(65 \%)$ przyznaje się do codziennego oglądania telewizji; są to przede wszystkim kobiety $(72 \%)$, osoby powyżej 35 roku życia (79\%), mieszkańcy wsi (77\%) i osoby niepracujące (91\%). Nie ma drugiego medium o takim zasięgu, zwłaszcza jeżeli weźmiemy pod uwagę, że nawet ci, którzy deklarują, że nie mają telewizora, tylko korzystają $\mathrm{z}$ internetu - bardzo często oglądają w nim programy telewizyjne, w tym informacyjne. Korzystają też z portali informacyjnych nadawców telewizyjnych.

Po drugie - dostępność. Media papierowe i internet, w przeciwieństwie do telewizji, wymagają odpowiednich kompetencji - umiejętności czytania, obsługi komputera i wyszukiwania informacji. Wymagają też większego zaangażowania ze strony odbiorcy. Przekaz telewizyjny jest łatwiejszy w percepcji, nie wymaga żadnych kompetencji i dociera do tych, którzy nie czytają lub czytają bardzo rzadko. Stanowi więc dla wielu odbiorców główne źródło informacji. Telewizja ma też tę zaletę, że nie wymaga znajomości konkretnego języka, ale bardziej uniwersalnego zainteresowania obrazem. To wszystko sprawia, że telewizja jako źródło łatwo dostępnej informacji przejęła rolę edukowania społeczeństwa, a władza wykorzystuje to w celu kształtowania postaw.

Po trzecie, przekaz telewizyjny jest dużo atrakcyjniejszy niż prasowy czy radiowy. Truizmem jest stwierdzenie, że składa się na niego obraz i dźwięk, warto jednak podkreślić niezwykłe zróżnicowanie przekazu telewizyjnego pod względem treści i formy. Charakterystyczne dla telewizji jest ciągłe wprowadzanie innowacji technologicznych - kolor (który zastąpił przekaz czarno-biały), relacje na żywo, animacje, przekazy równoległe ${ }^{34}$. Każdy z elementów związanych z treścią i formą przekazu może wpływać perswazyjnie na odbiorcę. Jak pokazują badania Piotra Francuza, można wskazać kilkadziesiąt kategorii formalnych, które mają wpływ na rozumienie treści wiadomości, a co za tym idzie - też na ich perswazyjność. Są to m.in.: liczba i czas ujęć, plan, ruch kamery, grafika, animacja, obecność ludzi w ujęciach, liczba wypowiadanych zdań i wyrazów ${ }^{35}$. Audiowizualność telewizji dystansuje więc prasę i radio, jeśli chodzi o zarządzanie emocjami - obraz jest zdecydowanie bardziej sugestywny niż słowo pisane i dźwięk. Potencjał perswazyjny wykorzystywany dla oddziaływania politycznego obrazu leży w:

\footnotetext{
${ }^{33}$ Raport oglądalności za rok 2014; http://www.wirtualnemedia.pl/artykul/telewizje-oglada-prawie-kazdy-polak-65-proc-codziennie-wideo [dostęp: 11.06.2016].

${ }^{34}$ P. Fortuna, dz. cyt., s. 14.

${ }^{35}$ P. Francuz, P. Fortuna, A. Szalkowska, M. Szubielska, Rozumienie telewizyjnych programów informacyjnych: studium porównawcze „Wiadomości” (TVP1), „Panorama” (TVP2), „Fakty” (TVN), ,Wydarzenia” (Polsat), Raport z badań 2006, cyt. za P. Fortuna, dz. cyt., s. 14.
} 
1) prostocie - dociera on łatwo do słabo wykształconego odbiorcy i upraszcza obraz rzeczywistości. Przekaz werbalny lepiej ukazuje złożoność zjawisk, a „wyjaśnić coś” oznacza: prowadzić abstrakcyjny dyskurs. Obraz jest wrogiem abstrakcji;

2) sugestywności - obraz przekazuje informacje w sposób bezpośredni, nie pozostawia wiele miejsca na niuanse, wątpliwości, hipotezy, jest produktem gotowym, wymaga tylko biernego zarejestrowania;

3) złudzeniu realizmu - odbiorcy trudno wątpić w to, co widzi, bo obraz stwarza przekonanie o autentyczności przedstawionych zdarzeń. Istnieje powszechne przekonanie, że obraz nie kłamie. Jest tym, czym jest. Mówi sam za siebie. Oczywiście - telewizyjny obraz może kłamać. Fałszuje rzeczywistość w tym sensie, że ją selekcjonuje i dekontekstualizuje, np. opiera się na bliskich planach pozbawionych tła tworzącego kontekst ${ }^{36}$. Ale oczy i tak wierzą temu, co widzą. Rzeczy widziane stają się realne, a tym samym prawdziwe. Obraz daje też możliwość uczestniczenia w zbiorowych ceremoniach, widowiskach, pogrzebach, pozwala współuczestniczyć w zdarzeniach, do których normalnie człowiek nie ma dostępu;

4) likwidowaniu różnorodności autorytetów poznawczych, a istnienie tej różnorodności zapewnia każdemu możliwość wyboru: komu ufać, a kto jest niewiarygodny. W telewizji sam obraz jest autorytetem - $\mathrm{i}$ to najbardziej wiarygodnym.

Audiowizualność powoduje, że perswazja w telewizji oparta jest nie na wymianie argumentów i myśli, a więc nie na logos, ale na retorycznym pathos. Problemy wielokrotnie nie są widzialne, tymczasem telewizja uprzywilejowuje widzialne i ono atakuje emocje. W kulturze pisanej najczęściej nie dochodzi do takiego rozgrzania i emocjonalnego współuczestnictwa jak w telewizji, radio też czyni to w mniejszym stopniu niż telewizja.

I w końcu - telewizja jest medium na pewno łatwiej kontrolowalnym niż np. internet, dlatego jest bardziej pożądanym narzędziem oddziaływania politycznego.

Telewizja, posiadając perswazyjną moc oddziaływania na opinię publiczną, ma możliwość wpływania na system przekonań panujący w danej grupie. Może modyfikować społecznie zaakceptowany katalog poglądów i norm, przekonywać do konkretnych racji poprzez selekcję i hierarchizowanie pewnych wydarzeń oraz koncentrowanie uwagi widza na wybranych elementach rzeczywistość. Może też wykluczać ze zbiorowej świadomości wydarzenia przez siebie pomijane.

${ }^{36}$ Zob. G. Sartori, Homo videns, przeł. J. Uszyński, Telewizja Polska S.A., Warszawa 2005, s. 50; T. Tokarz, Obraz jako narzędzie propagandy politycznej, [w:] Przestrzenie wizualne i akustyczne człowieka. Antropologia audiowizualna jako przedmiot i metoda badań, red. A. Janiak, W. Krzemińska, A. Wojtasik-Tokarz, Wydawnictwo Naukowe DSW, Wrocław 2007, s. 336-338. 


\section{Skuteczność oddziaływania}

Na koniec warto powiedzieć, że o ile bez problemu udało się wskazać techniki oddziaływania telewizji i określić jej potencjał dla działań propagandowych, to nie jesteśmy w stanie wiarygodnie określić skuteczności tego oddziaływania. A więc odpowiedzieć na pytanie, w jakim stopniu telewizja (przekaz telewizyjny) może wpłynąć na postawy i przekonania odbiorców, a także ich zachowania, na czym niewątpliwie najbardziej zależy politykom.

Bardzo trudno jest zmierzyć skuteczność oddziaływania środków masowego przekazu ${ }^{37}$, jest ona bowiem uzależniona od wielu czynników. Po stronie odbiorcy to chociażby: jego światopogląd, wpływ środowiska rodzinnego, wychowanie, styl i poziomu życia czy wykształcenie ${ }^{38}$. Nie da się ukryć, że interpretujemy informacje przekazywane przez środki masowego przekazu w kategoriach własnego kontekstu społecznego. Natomiast po stronie medialnego nadawcy ważna jest wiarygodność. Każdy przekaz ma większą skuteczność, gdy pochodzi ze źródła postrzeganego jako bardziej wiarygodne ${ }^{39}$. W kontekście wiadomości telewizyjnych „bardziej wiarygodne” oznacza: obiektywne. Kontrola mediów przez władze powoduje, że ich wiarygodność słabnie - w PRL znany był slogan „telewizja kłamie”. Oczywiście taki wpływ jest silniejszy, gdy brakuje kontrfaktów, a więc telewizja ma tym większy wpływ, im słabsze są pozostałe media, zwłaszcza gazety (bo radio w mniejszym stopniu zajmuje się polityką). W dobie wolnego dostępu do różnych mediów bardzo trudno spełnić ten warunek. Można natomiast próbować zdeprecjonować inne środki masowego

${ }^{37}$ Problem skuteczności oddziaływania mediów jest przedmiotem badań psychologów i socjologów od lat 20. XX wieku. Stanowiska badaczy ewoluowały od przekonania o niemal magicznym wpływie mediów na psychikę i zachowania bezbronnych, łatwowiernych, biernych odbiorców w modelu „magicznego pocisku” (inaczej teoria wpływów bezpośrednich wykorzystywana przez behawiorystów i psychoanalityków w latach 20.-30. XX wieku), przez przekonanie o tym, że odbiorca jest aktywnie zaangażowany w proces podejmowania decyzji i postępuje racjonalnie, a ponieważ skuteczny proces perswazji wymaga przejścia przez niego kilku etapów: przyciągnięcie uwagi, przyswojenie argumentacji, uznanie argumentacji za prawdziwą i zaakceptowanie jej, w końcu - dostrzeżenie korzyści wynikającej z poddania się perswazji, to prawdopodobieństwo tego, że odbiorca dotrze do ostatniego etapu jest znikome (model przetwarzania informacji w latach 40. XX wieku), po najbardziej znaną teorię postaw w psychologii społecznej ELM - Elaboration Likelihood Model of Persuasion (zob. R.E. Petty, J.R. Priester, Mass-media Attitude Change: Implications of the Elaboration Likelihood Model of Persuasion, [w:] Media effects. Advances in Theory and Research, (red.) J. Bryant, D. Zillmann, Erlbaum, Hillsdale, New York 1994, s. 91-122; D.F. Roberts., N. Macoby, Effects of mass communication, [w:] Handbook of social psychology, Vol. 2, (red.) G. Lindzey, E. Aronson, Random House, New York 1985, s. 539-598; R.E. Petty, J.T. Cacioppo, The Elaboration Likelihood Model of Persuasion, [w:] Advances in Experimental Social Psychology, Vol. 19, (red.) L. Berkowitz, Academic Press, New York 1986, s. 123-205; zob. też: A. Pratkanis, E. Aronson, dz. cyt., s. 24-39).

38 Por. T. Garret, Manipulacja a środki masowego przekazu, „Concilium” 1971, 1-10, s. 248-253.

${ }^{39}$ Por. A. Pratkanis, E. Aronson, dz. cyt., s. 107-136. 
przekazu i odebrać im wiarygodność, np. poprzez etykietowanie, co zresztą zarówno politycy, jak i niekiedy dziennikarze czynią.

Niewątpliwie, dzisiaj niewielu widzów nie zdaje sobie sprawy z sympatyzowania oglądanej przez siebie stacji z konkretnymi siłami politycznymi. Jak zauważa Charles Mills:

wiadomo, że ludzie mają tendencję do wybierania tych środków informacji masowej, z których enuncjacjami z góry się zgadzają. Istnieje swego rodzaju selekcja nowych opinii na podstawie opinii poprzednich. Nikt nie szuka kontrargumentów oferowanych przez alternatywne środki masowe. Określone programy radiowe, periodyki i dzienniki mają zwykle stałych odbiorców i dzięki temu utrwalają głoszone przez siebie poglądy w ich umysłach ${ }^{40}$.

Świadomość odbiorców dotycząca perswazyjności przekazów informacyjnych też jest duża. Badał to Paweł Fortuna ${ }^{41}$, który zaprezentował osobom testowanym listę programów telewizyjnych (m.in. reklamę telewizyjną, sitcom, program informacyjny, program sportowy, program dokumentalny, teleturniej, teatr telewizji) i poprosił o uporządkowanie ich ze względu na intencję oddziaływania perswazyjnego nadawców na widzów. W opinii badanych cel perswazyjny w największym stopniu dotyczy takich programów, jak: reklama TV, debata telewizyjna i właśnie program informacyjny, który z założenia powinien dążyć do ograniczania perswazji. Co więcej, manipulacyjne intencje są przypisywane wiadomościom telewizyjnym zazwyczaj w kontekście debaty politycznej. To wszystko jednak nie zmienia faktu, że widzowie ulegają magii szklanego ekranu i telewizja jest narzędziem chętnie wykorzystywanym przez władzę do wywierania wpływu, kształtowania lojalnych zwolenników i określonych postaw wobec kwestii społecznie ważnych.

\section{Bibliografia}

Arystoteles, Retoryka. Retoryka dla Aleksandra, tłum. H. Podbielski, Wydawnictwo Naukowe PWN, Warszawa 2004.

Barańczak S., Stowo, perswazja, kultura masowa, „Twórczość” 1975, nr 7, s. 44-59.

Barthes R., The Responsibility of Forms. Critical Essays on Music, Art, and Representation, Hill and Wang, New York 1985.

Bourdieu P., O telewizji. Panowanie dziennikarstwa, przeł. K. Sztandar-Sztanderska, A. Ziółkowska, red. M. Jacyno, Wydawnictwo Naukowe PWN, Warszawa 2009.

Bralczyk J., Manipulacja językowa, [w:] Dziennikarstwo i świat mediów, red. Z. Bauer, E. Chudziński, Universitas, Kraków 2004, s. 244-250.

${ }^{40}$ C.W. Mills, Elita władzy, oprac. i red. I. Rafelski, Książka i Wiedza, Warszawa 1961, s. 411-412.

${ }^{41}$ P. Fortuna, dz. cyt., s. 27. 
Cwalina W., Falkowski A., Marketing polityczny. Perspektywa psychologiczna, Gdańskie Wydawnictwo Psychologiczne, Gdańsk 2005.

Czuba K., Media i władza, Ad Astra, Warszawa 1995.

Czwarta władza? Jak polskie media wptywaja na opinię publiczna, red. W. Nentwig, Oficyna Wydawnicza „Głos Wielkopolski”, Poznań 1995.

Dobek-Ostrowska B., Fras J., Ociepka B., Teoria i praktyka propagandy, Wydawnictwo UWr, Wrocław 1999.

Dobek-Ostrowska B., Media masowe i aktorzy polityczni w świetle studiów nad komunikowaniem politycznym, Wydawnictwo UWr, Wrocław 2004.

Eco U., Semiologia życia codziennego, przeł. J. Ugniewska, P. Salwa, Czytelnik, Warszawa 1999.

Fortuna P., Psychologiczne mechanizmy obrony przed perswazyjnym wpływem telewizji, Towarzystwo Naukowe KUL, Lublin 2007.

Garret T., Manipulacja a środki masowego przekazu, „Concilium” 1-0 1971, s. 248-253.

Grzegorczykowa R., Problem funkcji języka i tekstu w świetle teorii aktów mowy, [w:] Język a kultura, t. 4: Funkcje języka i wypowiedzi, red. J. Bartmiński, R. Grzegorczykowa, Wydawnictwo „Wiedza o Kulturze”, Wrocław 1991, s. 11-28.

Kamińska-Szmaj I., Propaganda, perswazja, manipulacja - próba uporządkowania pojęć, [w:] Manipulacja w języku, red. P. Krzyżanowski, P. Nowak, Wydawnictwo Uniwersytetu Marii Curie-Skłodowskiej, Lublin 2004, s. 13-27.

Karnowski M., Mistewicz E., Anatomia władzy. Mistewicz kontra Karnowski, Czerwone i Czarne, Warszawa 2010.

McLuhan M., Zrozumieć media: przedtużenie człowieka, przeł. N. Szczucka, Wydawnictwa Naukowo-Techniczne, Warszawa 2005.

Mills C.W., Elita władzy, oprac. i red. I. Rafelski, Książka i Wiedza, Warszawa 1961.

Mrozowski M., Media masowe. Władza, rozrywka, biznes, Wydawnictwo Aspra-Jr, Warszawa 2001.

Nowak P., Retoryka a propaganda polityczna, [w:] Retoryka, red. M. Barłowska, A. Budzyńska-Daca, P. Wilczek, Wydawnictwo Naukowe PWN, Warszawa 2008, s. 207-226.

Petty R.E., Cacioppo J.T., The Elaboration Likelihood Model of Persuasion, [w:] Advances in Experimental Social Psychology, Vol. 19, (red.) L. Berkowitz, Academic Press, New York 1986, s.123-205.

Petty R.E., Priester J.R., Mass-media Attitude Change. Implications of the Elaboration Likelihood Model of Persuasion, [w:] Media effects: Advances in Theory and Research, (red.) J. Bryant, D. Zillmann, Erlbaum, Hillsdale, New York 1994, s. 91-122.

Pratkanis A., Aronson E., Wiek propagandy. Używanie i nadużywanie perswazji na co dzień, przeł. J. Radzicki, M. Szuster, Wydawnictwo Naukowe PWN, Warszawa 2005.

Puzynina J., Język wartości, Wydawnictwo Naukowe PWN, Warszawa 1992.

Roberts D.F., Macoby N., Effects of mass communication, [w:] Handbook of social psychology (Vol. 2), (red.) G. Lindzey, E. Aronson, Random House, New York 1985, s. 539-598

Różycka M., Panowanie - czy władza-mediów?, [w:] Władza mediów, red. W. Piątkowska-Stepaniak, A. Drosik, Wydawnictwo UO, Opole 2010, s. 49-66.

Sartori G., Homo videns, przeł. J. Uszyński, Telewizja Polska S.A., Warszawa 2005.

Shanto I., Kinder D.B., News that Matters. Television and American Opinion, University of Chicago Press, Chicago 1987.

Sternberg R.J., Psychologia poznawcza, przeł. E. Czerniawska, A. Matczak, Warszawa 2001. 
Thomson O., Historia propagandy, przeł. S. Głąbiński, Wydawnictwo „Książka i Wiedza”, Warszawa 2001.

Tokarz T., Obraz jako narzędzie propagandy politycznej, [w:] Przestrzenie wizualne i akustyczne człowieka. Antropologia audiowizualna jako przedmiot i metoda badań, red. A. Janiak, W. Krzemińska, A. Wojtasik-Tokarz, Wydawnictwo Naukowe DSW, Wrocław 2007, s. 332-343.

Wasilewski J., Skibiński A., Prowadzeni słowami. Retoryka motywacji w komunikacji publicznej, Wydawnictwo Difin, Warszawa 2008.

Władza mediów, red. W. Piątkowska-Stepaniak, A. Drosik, Wydawnictwo UO, Opole 2010.

Żórawski K., Długi stół. Skrypt dla dziennikarzy programów informacyjnych, Telewizja Polska S.A., Warszawa 2004.

Barbara Sobczak

Television as a tool of political propaganda

(Summary)

The objective of the article is to analyze the persuasive potential of television, which makes it a useful tool of political propaganda. The starting point is a quantitative and qualitative analysis of the materials broadcast on the public television TVP Info on 10.04.2016, the 6th anniversary of the Smolensk airplane crash. It allows for the identification of specific tools of manipulation used by the broadcaster to shape the public opinion (i.a. gatekeeping, framing, emotionalization of the message), as well as the factors that determine the usefulness of television in political propaganda activities, namely: coverage, accessibility, audio-visual nature and the possibility of controlling the message. The audio-visual nature is especially important in this regard. Because of it, persuasion in television is not based on the exchange of arguments and thoughts and therefore not on the logos, but to a large extent on manipulation through images and symbols, and therefore on the rhetorical pathos. The image simplifies reality, it is suggestive (it transmits information in a direct way, does not leave much room for nuance), it gives the illusion of realism (it creates a belief about the authenticity of the presented event), and removes the variety of cognitive authorities (on the television the image itself is the authority).

Keywords: television, persuasion, manipulation, propaganda, politics, gatekeeping. 